
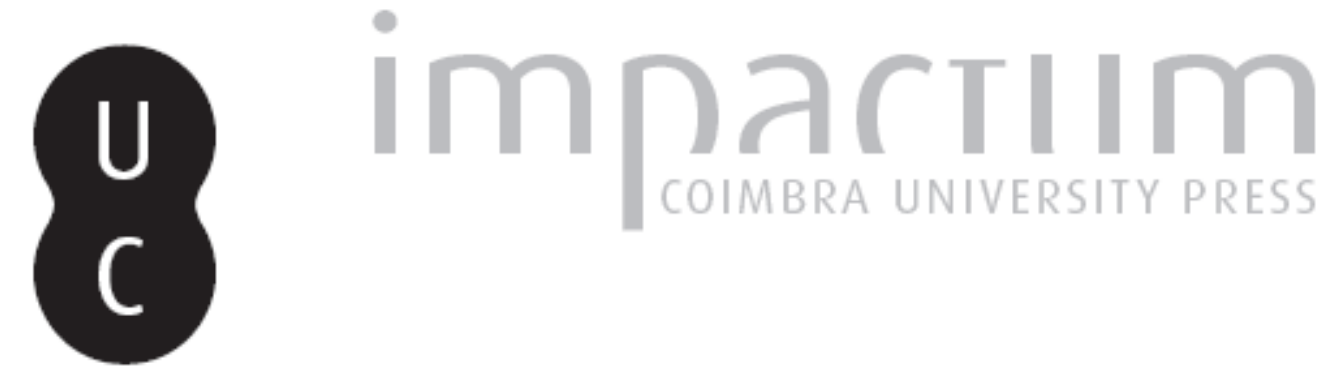

A afirmação da profissão de jornalista em Portugal: um poder entre poderes?

Autor(es): $\quad$ Vargues, Isabel Nobre

Publicado por: Imprensa da Universidade de Coimbra

URL persistente:

URI:http://hdl.handle.net/10316.2/43718

DOI: DOI:https://doi.org/10.14195/2183-8925_24_5

Accessed : $\quad$ 26-Apr-2023 01:35:16

A navegação consulta e descarregamento dos títulos inseridos nas Bibliotecas Digitais UC Digitalis, UC Pombalina e UC Impactum, pressupõem a aceitação plena e sem reservas dos Termos e Condições de Uso destas Bibliotecas Digitais, disponíveis em https://digitalis.uc.pt/pt-pt/termos.

Conforme exposto nos referidos Termos e Condições de Uso, o descarregamento de títulos de acesso restrito requer uma licença válida de autorização devendo o utilizador aceder ao(s) documento(s) a partir de um endereço de IP da instituição detentora da supramencionada licença.

Ao utilizador é apenas permitido o descarregamento para uso pessoal, pelo que o emprego do(s) título(s) descarregado(s) para outro fim, designadamente comercial, carece de autorização do respetivo autor ou editor da obra.

Na medida em que todas as obras da UC Digitalis se encontram protegidas pelo Código do Direito de Autor e Direitos Conexos e demais legislação aplicável, toda a cópia, parcial ou total, deste documento, nos casos em que é legalmente admitida, deverá conter ou fazer-se acompanhar por este aviso.

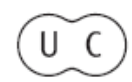



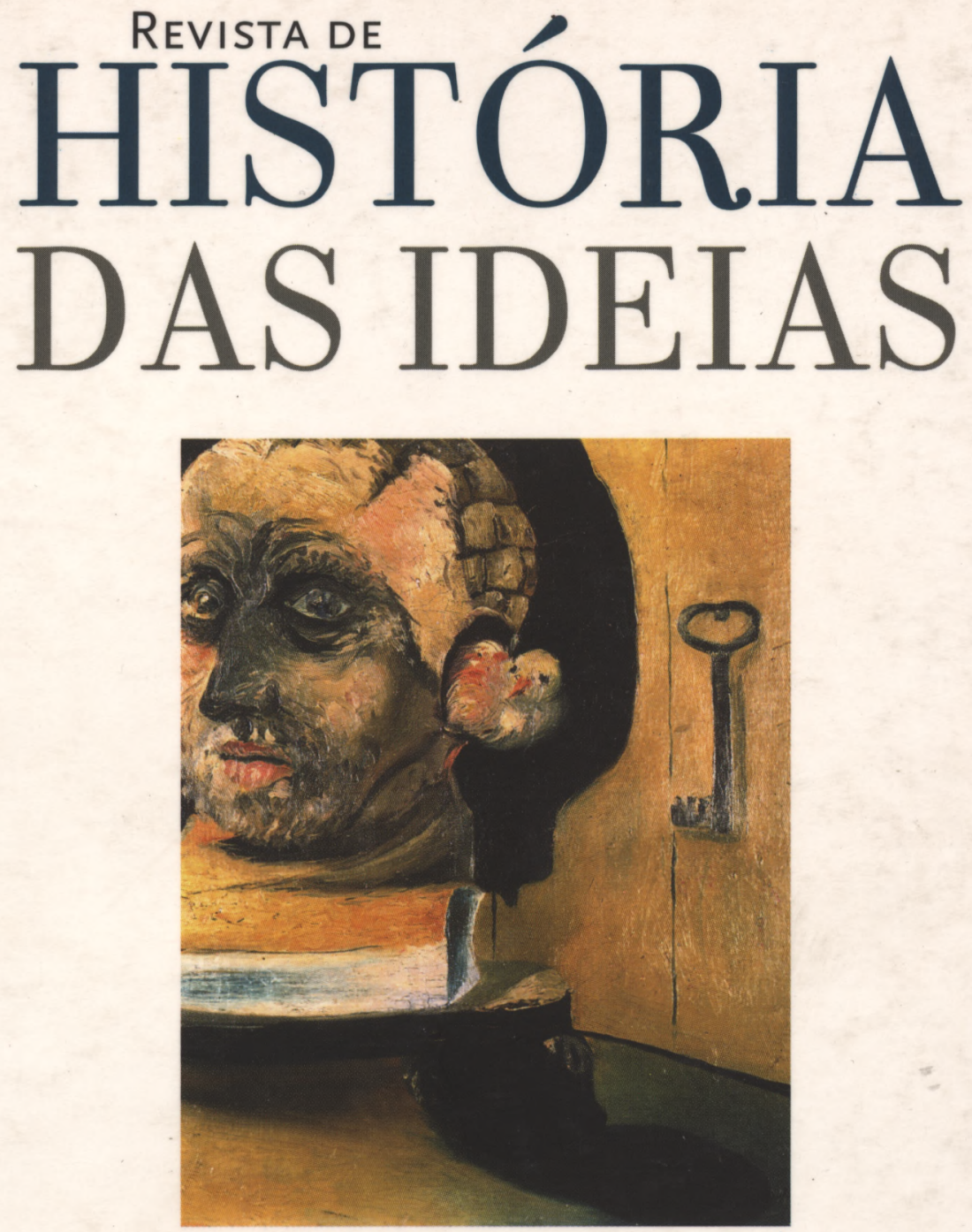

OS INTELECTUAIS E OS PODERES

Volume 24, 2003

INSTITUTO DE HISTÓRIA E TEORIA DAS IDEIAS

Faculdade de Letras da Universidade de Coimbra 


\section{A AFIRMAÇÃO DA PROFISSÃO DE JORNALISTA EM PORTUGAL: UM PODER ENTRE PODERES?}

Escreve Michel Guénaire em Déclin et renaissance du pouvoir, no capítulo intitulado "La presse ou la fin du pouvoir" (Guénaire, 2002, pp. 113-124), que um dos enigmas da democracia moderna reside no magistério que a imprensa conquistou. Esse poder constituiu-se sem ser objecto de uma eleição e impôs-se como se dotado de uma legitimidade própria. Esse poder enuncia uma forma de opinião acabada e incontestável, às vezes sagrada, à qual se deve submeter o poder político. A sua força nasce a partir das fraquezas do poder. Estamos perante o fim ou uma metamorfose do poder? Hoje, muitos jornais determinam a conduta dos governos e, para o provar, exemplifica com o Finantial Times e com a sua influência nos actores do capitalismo mundial. Ainda segundo o Autor citado, a informação é a última revolução em marcha contra o poder no mundo, uma revolução política que visa o fim do poder.

É por isso inegável reconhecer o papel que os jornalistas desempenham nas sociedades contemporâneas e nos regimes democráticos em particular, onde são uma profissão de grande responsabilidade. Muitas vezes se qualifica o bom e o mau jornalismo, situando-o entre a necessidade quotidiana da informação e a sua manipulação, ou a atitude de desinformação com que muitas vezes nos confrontamos num panorama mediático em constante mutação. De resto, o poder dos media é hoje uma questão

\footnotetext{
* Faculdade de Letras da Universidade de Coimbra e CEIS20.
} 
em debate. Naturalmente, esse papel foi uma construção que acompanhou o desenvolvimento das sociedades contemporâneas, sobretudo desde os fins do século XIX, quando o jornalismo começou a afirmar-se, sendo definido como um "quarto poder" face aos outros poderes executivo (governo), legislativo (parlamento) e judicial (juizes e tribunais). De Sa Magesté la Presse, livro de Stéphane Lauzanne, ao capítulo de Michel Guénaire citado, um longo caminho foi percorrido.

A autonomia do jornalismo e do jornalista como profissional foi alcançada quando um novo personagem se separou quer da esfera política quer esfera da literatura. Rémy Rieffel define uma elite dos jornalistas, considerando-os como "arautos da informação" (Rieffel,1984). Tomando de empréstimo o título de Thomas Ferenczi, a invenção do jornalismo acontece nesse momento, lá onde um novo personagem, $\mathrm{o}$ jornalista, começa a afirmar-se no espaço público; e, em França, isso ocorreu no século XIX (Ferenczi, 1996). Christian Delporte foi um dos primeiros autores a reflectir sobre o aparecimento dos intelectuais e a construção da profissão de jornalista em França entre 1880 e 1950 (Delporte, 1999).

Na época contemporânea, desde cedo a política foi associada à imprensa e ao jornalismo: basta recordar, em Inglaterra, Winston Churchill e, em França, conhece-se o papel decisivo desempenhado por políticos como Jean Jaurés, Aristide Briand, Léon Blum, ou por escritores como Honoré de Balzac, Émile Zola ou Albert Camus. Também em Portugal esse mesmo papel foi exercido por políticos e escritores públicos, desde 1820 , a partir dos combates políticos e ideológicos que então se travaram. Entre nós, é com a mesma designação, a de homens de letras, escritores e jornalistas, que são conhecidos todos os profissionais de letras no século XIX. Almeida Garrett, José Estevão, Alexandre Herculano, António Feliciano de Castilho, Teixeira de Vasconcelos, Mendes Leal, Latino Coelho, Oliveira Martins, Eça de Queirós são alguns desses escritores públicos mais conhecidos, que também foram jornalistas em certos momentos das suas vidas. Só mais tarde surgiu a designação de intelectuais.

Também o exercício da profissão de homem de letras era cumulativo com o desempenho de muitas outras actividades, nomeadamente políticas, científicas e artísticas e mesmo com as profissões liberais. Por esse motivo, não surpreende a ocupação de altos cargos políticos por muitos deles. Tal como em França, Inglaterra e Espanha, também em Portugal os profissionais do jornalismo mantinham fortes laços com a política e 
com a literatura, exercendo já então uma influência considerável na sociedade através de uma imprensa de opinião, que só mais tarde se tornaria noticiosa e informativa.

Como esquecer os pioneiros jornalistas António Rodrigues Sampaio, o "Sampaio da Revolução", Eduardo Coelho fundador do Diário de Notícias, Mariano de Carvalho, António Enes, Pinheiro Chagas, Magalhães Lima ou Emídio Navarro? Todos foram grandes jornalistas e os jornais que dirigiram ou onde escreveram fizeram escola. "Paralelamente aos fins partidários, faziam escola de civismo, criando o amor do forum, guiando e adestrando a opinião e o julgamento em face do filme da vida e levando às camadas médias de leitores os produtos requintados da literatura, da arte, do pensamento. $O$ teatro, por exemplo, foi modernizado e difundido em Portugal pelos jornais de 1850 a 1900, que avaliavam as peças, discutiam as interpretações e faziam do actor e da actriz os ídolos do dia [...] A imprensa prolongava e animava a literatura, supria os fracos benesses que a indústria editorial arbitrava aos autores" (Nemésio, 1943). Depois, a tradição de um jornalismo personalizado alterou-se com a industrialização do jornal, que se tornou mais num repertório de notícias e de anúncios. Consequentemente, o carácter literário e doutrinal do jornal foi sendo substituído por uma especialização mais informativa. Em 1943, Vitorino Nemésio, em artigo publicado no Diário Popular (29 de Setembro), reflectia sobre as vicissitudes da imprensa naquele tempo, relevando, entre outras, "a questão profissional com seus aspectos múltiplos: preparação, remuneração, quadros; a necessidade de convencer o jornalista a separar em si o possível literato ou escritor-de-livro, do perfeito técnico da generalidade e da efeméride. Concisão da escrita, escrúpulo no apuramento dos factos e no emprego das nomenclaturas, sobriedade no perigoso manejo da actualidade, que excita $o$ público para bem ou para mal".

Impõe-se assim, como ponto de partida, que se conheça melhor o modo como a profissão se afirmou em Portugal. Só depois estaremos em condições de compreender o problema complexo da transformação da opinião, da notícia e da informação numa dimensão do próprio poder: é o jornalismo o simbólico "quarto poder", o primeiro poder, o quinto poder, um "poder frustrado" (Agee, W. e Traquina, N., 1988), um "quarto equívoco" (Mesquita, M., 2003)? 


\section{A afirmação de uma profissão}

Em meados do século XIX, com Costa Cabral, as regras do jogo político alteraram-se com inúmeras transferências e demissões de juízes, militares e outros funcionários; e os homens de letras, isto é, os intelectuais, por força do decreto de 1 de Agosto de 1844, já subordinados aos dirigentes partidários, passaram também a ficar na dependência do poder central . "O favor político, sobretudo exercido sem discrição, era uma norma perigosa na medida em que vencedores e vencidos trocavam frequentemente de papéis [...] assim envolvidos embora com os grupos dirigentes, ligados a fracções partidárias e ocupando cargos parlamentares e postos na Administração, os intelectuais esforçar-se-iam por criar condições que lhes permitissem ficar menos sujeitos à dependência das instâncias políticas" (Santos,1983, p. 23).

Um dos nossos mais conhecidos escritores públicos, homem de letras e, também, um dos nossos primeiros jornalistas, Almeida Garrett, em 3 de Setembro de1846, apresentou um texto sobre a neutralidade literária, escrito que muito justamente deve ser considerado pioneiro na definição da autonomia do homem de letras; foi lido no Grémio Literário, em sessão da Liga ou Associação Promotora dos Melhoramentos da Imprensa, e saiu no jornal $A$ Revolução de Setembro, em 5 de Setembro.

A intervenção dos homens de letras, como um grupo social distinto, tornou-se muito activa no tempo de Costa Cabral: em 1844, contestando o decreto de 1 de Agosto e, em 1850, quando foi apresentado o projecto de lei relativo à imprensa. Em 18 de Fevereiro, foi divulgado um abaixo-assinado dos "homens de letras, autores e jornalistas de Lisboa", documento mais conhecido como o "protesto dos sessenta", o qual, segundo Gomes de Amorim, terá sido redigido por Almeida Garrett e por Alexandre Herculano.

Outros intelectuais aderiram ao protesto no Porto e em Coimbra. Alunos e professores da Universidade rejeitaram aquele projecto de lei, em nome da autonomia da instituição e da liberdade de expressão; o seu protesto foi vencido com a publicação da lei de 3 de Agosto de 1850, vulgarmente conhecida pelo nome de "Lei da Rolha". Porém, esta foi revogada em 1851, com a Regeneração, tendo-se então iniciado uma nova época na história do jornalismo.

A imprensa jornalística em Portugal, nos meados do século XIX, alcançou um novo papel no espaço público, o que explica o poder 
atractivo que exerceu sobre a maior parte dos que almejavam o estatuto de escritor e de singrar na política. Nesse sentido, afirma Maria de Lurdes Lima dos Santos: "dificilmente se encontra algum intelectual que não tenha feito jornalismo [...] A cotação da carreira jornalística subia e a imprensa aparecia como uma via de profissionalização consideravelmente interessante [...] O jornalismo constituía uma espécie de estágio e de reserva onde se cooptava o novo pessoal político" (Santos, 1983, p. 20).

A autonomia dessas profissões foi uma consequência fundamental da afirmação da profissão de jornalista em Portugal e esta desenvolveu-se, em novos moldes, desde finais do século XIX, a partir da realização dos primeiros congressos internacionais e exposições nacionais, da fundação das primeiras associações, e da importância dada à questão do ensino do jornalismo.

\section{Os primeiros congressos internacionais}

Os primeiros congressos internacionais de jornalistas iniciaram-se em 1893, em Londres. Depois terão lugar em Antuérpia (1894), Bordéus (1895), Budapeste (1896), Estocolmo (1897), Lisboa (1898), Roma (1899) e Paris (1900).

Eduardo Coelho, o fundador do Diário de Notícias, participou no Congresso de Antuérpia, em 1894, com uma memória, onde reflectiu sobre os cerca de quatrocentos periódicos publicados em Portugal. Alfredo da Cunha, seu genro e sucessor, teve um papel importante no V Congresso Internacional de Imprensa, realizado em Lisboa, em 1898, o primeiro no nosso país. Aí apresentou a memória, em francês, La presse periodique au Portugal, texto mais tarde traduzido e publicado, como apêndice final, no seu livro O Diário de Notícias. A sua fundação e os seus fundadores (1914).

Este Autor, dando conta da enorme transformação que o jornalismo conhecera em França, e defendendo que, com o aparecimento do Diário de Notícias, o mesmo sucedera em Portugal (pois teve como principal consequência uma mudança na profissão de jornalista), afirma: "O antigo jornalismo era apenas um agente de propaganda, uma arma de combate; o novo jornalismo tornou-se ao mesmo tempo uma indústria, pela importância dos capitais nele empregados e pela adopção de processos mecânicos consideráveis"; e mais adiante acrescenta: "O trabalho jorna- 
lístico principia a ter uma remuneração menos mesquinha e a poder constituir para muitos um exclusivo modo de vida. Porque, se a fundação de numerosas folhas políticas, a partir do segundo quartel deste século, concorrera para se tornar, em quantidade e qualidade, importante e influente a classe dos jornalistas, estes, como aliás ainda hoje sucede a tantos, a pouco mais aspiravam, ao escreverem para os periódicos, do que a fazer deles escola para uma cadeira no parlamento ou para um emprego público que lhes desse, por conta do Estado, o que os seus jornais não podiam proporcionar-lhes" (Cunha, 1914, p. 284).

Como vimos, os primeiros congressos internacionais de jornalistas tiveram uma periodicidade anual até 1900 . O primeiro, em Londres, foi organizado por jornalistas ingleses, em Setembro de 1893. Nele se salientou a delegação francesa, liderada por Émile Zola. Aí, o escritor prestou homenagem à "excelente ideia em querer relevar a dignidade da profissão de jornalista, de querer criar uma verdadeira corporação" (Ferenczi, 1996, p. 248). No segundo congresso - ocorrido em 1894, em Antuérpia, e presidido por Wilhelm Singer (um jornalista delegado da Áustria-Hungria, Director do Neues Wiener Tagblatt, e que veio a salientarse no congresso realizado em Lisboa em 1898) - foi criado um organismo central de associações de imprensa. Nele participou Brito Aranha, que apresentou um relatório sobre os periódicos portugueses. No de Budapeste (1896), criou-se a União Internacional das Associações de Imprensa, que pretendia assegurar uma assistência recíproca entre os jornalistas, estabelecer os usos e costumes do jornalismo, e contribuir para a elevação gradual do nível moral e intelectual dos associados. Os congressos que se seguiram em 1897 (Estocolmo), em 1898 (Lisboa) e em 1899 (Roma) contribuíram para a defesa dos interesses gerais dos jornalistas como grupo social emergente. Em 1900, o de Paris foi dedicado à carta internacional dos jornalistas, à propriedade artística, às tarifas postais, e à escola de jornalismo.

Quando hoje se analisa o modo como os jornalistas e o seu trabalho foram sendo reconhecidos, no passado, como um grupo social emergente, há um facto anterior que não se pode menosprezar. No momento das grandes comemorações centenárias oitocentistas - promovidas por republicanos e outros intelectuais liberais (estudadas, entre outros, por Fernando Catroga e Maria Manuela Tavares Ribeiro), em duas delas, em 1880, na celebração do centenário camoniano, e, em 1882, na celebração do centenário pombalino, a imprensa e a primeira Associação de 


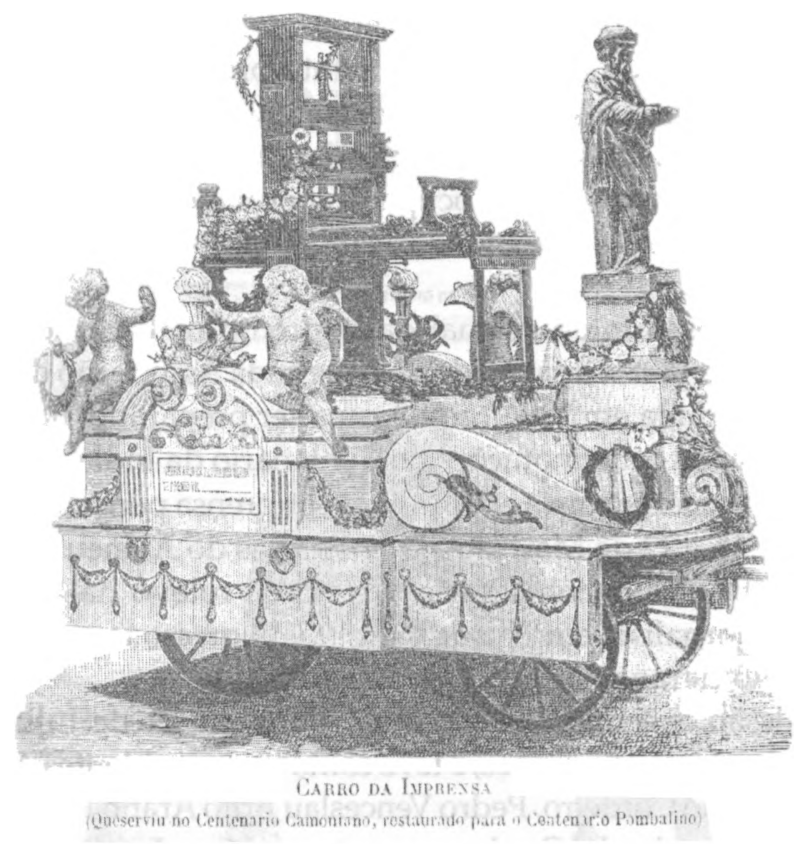

Jornalistas tiveram um lugar de destaque. Nos dois cortejos cívicos realizados em Lisboa, um dos carros triunfais simbolizou a imprensa. O mesmo veículo será depois transformado e decorado com uma estátua de Gutemberg, vindo a circular como o carro da Associação Tipográfica, no cortejo da homenagem a Garrett, em 3 de Maio de 1903. Refira-se ainda que, nos três cortejos, a representação da classe dos jornalistas foi considerável, com a presença de muitos membros da Associação de Jornalistas e de redactores de vários jornais (Dicionário Bibliográfico Português de Inocêncio Francisco da Silva, tomo XIX, p. 65).

Sinal evidente da evolução da ciasse jornalística no mundo foi também o inquérito lançado, em 1928, pelo Bureau Internacional do Trabalho (BIT) às organizações profissionais sobre as condições de trabalho e de vida dos jornalistas. O relatório foi considerado por Luís Teixeira, presidente do Sindicato dos Jornalistas, como o documento mais completo e elucidativo sobre o problema dos profissionais da imprensa. Segundo ele, "as associações de imprensa que noutros tempos admitiam sem dificuldade, lado a lado com os jornalistas profissionais, muitas outras pessoas - literatos, professores, etc. - que apenas ocasionalmente estavam 
relacionadas com os jornais, revelavam, já em 1928, nítida tendência para se reconstruírem numa base estritamente profissional. Através delas começou o combate dos jornalistas contra o sistema da múltipla colaboração, considerado causa determinante dos ordenados baixos, ao mesmo tempo que procuravam obter ocupação permanente e suficientemente retribuída para evitar a necessidade de procurar trabalho noutros jornais" (Teixeira, 1945).

O V Congresso Internacional da Imprensa realizou-se em Lisboa, em Setembro de 1898. Organizado pela segunda Associação de Jornalistas de Lisboa (fundada em 1896), começou a ser preparado, no âmbito das festas relativas às comemorações do Centenário da Índia, para ter lugar em Maio, juntamente com a exposição da imprensa periódica, que esteve aberta entre 15 e 22 de Maio de 1898 nas salas do Ateneu Comercial de Lisboa. Ambos os eventos tiveram grande relevo na afirmação da profissão de jornalista em Portugal, e o V Congresso tornou o país mais conhecido no estrangeiro.

A comissão executiva portuguesa, eleita em 11 de Julho de 1898, foi presidida por António Enes, e teve como vice presidentes A. J. Ferreira da Silva, Luciano Cordeiro, Pedro Venceslau Brito Aranha e Z. Consiglieri Pedroso, e Alfredo da Cunha como tesoureiro. Integraram ainda a comissão, como secretários e vogais, outros nomes ilustres do jornalismo português: Magalhães Lima, Silva Pereira, Fernandes Costa, Silva Graça. Inscreveram-se nele mais de trezentos jornalistas estrangeiros (franceses, alemães, ingleses, austríacos, belgas, dinamarqueses, holandeses, espanhol, americanos, finlandeses, húngaros, italianos, noruegueses, russos, suecos, suíços, e um transvaaliano) e quarenta e quatro portugueses, além de quarenta e sete senhoras. O número de participantes franceses,102, foi o maior, logo seguido de 37 italianos e de 34 húngaros, entre outras nacionalidades. Registe-se, a título de curiosidade, que apenas um jornalista espanhol compareceu. A este facto não será certamente alheia a situação peculiar espanhola nesse ano de 1898: o "desastre de 98".

A sessão inaugural, em 26 de Setembro, teve lugar na Sala Portugal, na Sociedade de Geografia. Wilhelm Singer, presidente do Congresso Internacional, leu uma alocução inaugural, em francês. Depois falou, também em francês, o rei $\mathrm{D}$. Carlos. À noite, teve lugar uma recepção sumptuosa na Câmara Municipal de Lisboa, que se prolongou pela madrugada. A 27 de Setembro, a $1^{\text {a }}$ sessão plenária começou com a leitura 

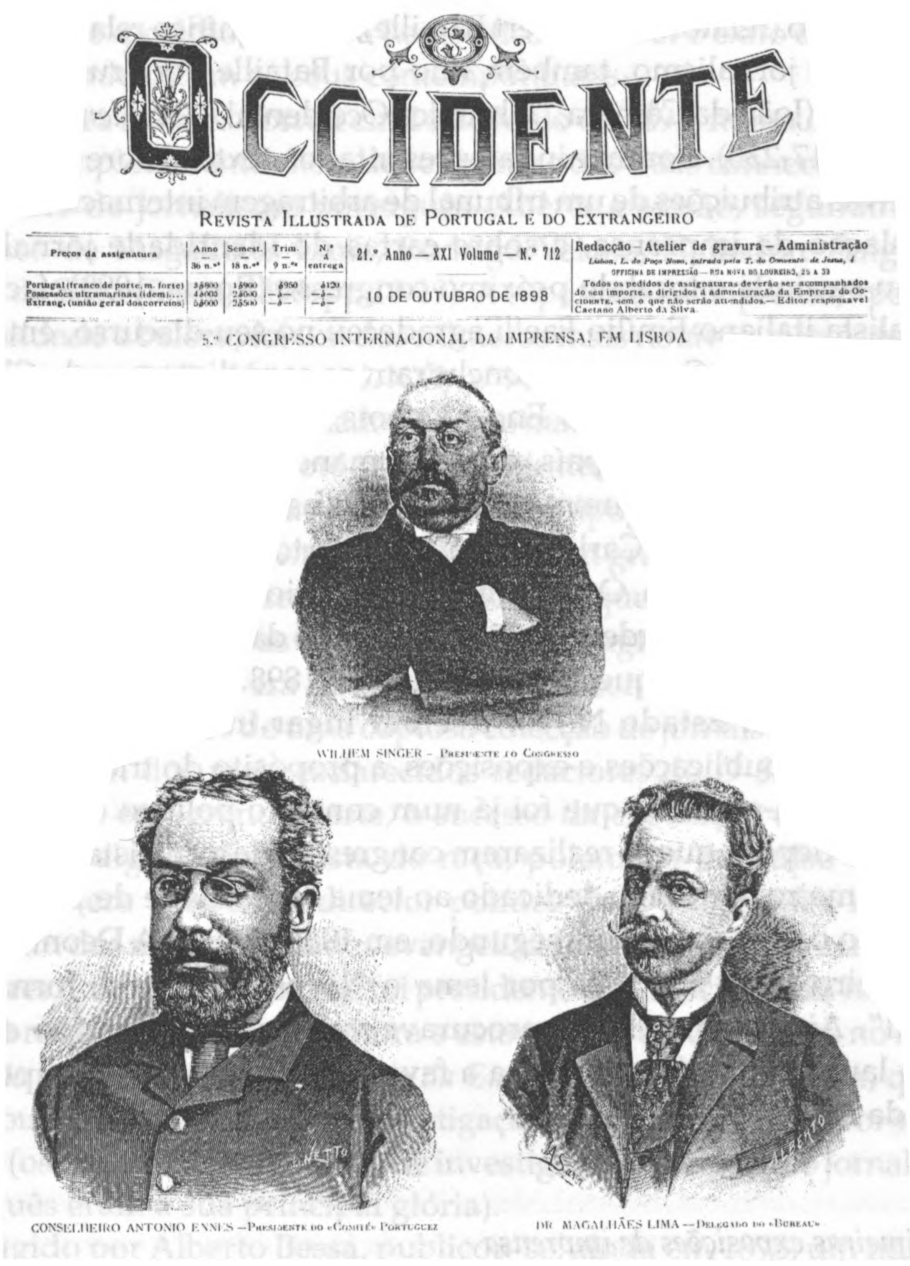

de vários relatórios. À tarde, os congressistas deslocaram-se, em combóio, do Rossio a Sintra e à Pena. As sessões de 28 e 29 de Setembro foram as mais produtivas. Os temas abordados foram vários: tarifas telegráficas internacionais (relatório do espanhol A. de Beraza); criação e funcionamento do gabinete internacional dos correspondentes (relatórios do italiano M. Torelli e do sueco Yanzon); propriedade literária dos artigos políticos (relatórios do alemão Osterieth e do francês Albert Bataille (Director do Figaro), tema que suscitou uma acalorada discussão; o ensino profissional 
do jornalismo (relatório de Albert Bataille); o "magnífico relatório" sobre o ensino do jornalismo, também lido por Bataille, foi "ruidosamente aplaudido" João da Câmara, "Chronica Occidental," Occidente, vol. XXI, 1898, pp. 217-230). Foram ainda apresentados textos sobre a criação e respectivas atribuições de um tribunal de arbitragem internacional, sobre a legislação da imprensa, e sobre cartas de identidade jornalística. Decidiu-se ainda o local do próximo congresso (Roma, 1899), facto que o jornalista italiano Emílio Faelli agradeceu no seu discurso, em latim. Os trabalhos do V Congresso concluíram-se com discursos de Claretie, Magalhães Lima e António Enes. Depois, os congressistas puderam apreciar melhor o nosso país, onde permaneceram até 2 de Outubro, visitando Tomar, dando um passeio no Tejo, assistindo a uma tourada e a um espectáculo em S. Carlos, visitando o Porto, Gaia, Leixões e a região vinícola do Alto Douro. O Congresso Internacional de Lisboa projectou Portugal e colocou na ordem do dia a afirmação da profissão de jornalista. O jornalismo saiu enriquecido nesse ano de 1898.

Em 1941, no Estado Novo, tiveram lugar inúmeras realizações, conferências, publicações e exposições, a propósito do tricentenário da Gazeta. Refira-se ainda que foi já num contexto político democrático, um século depois, que se realizaram congressos de jornalistas portugueses: o primeiro, em 1982, dedicado ao tema "Liberdade de Expressão Expressão da Liberdade"; o segundo, em 1986, sobre "A Deontologia"; e o terceiro, em 1998, teve por lema o "Jornalismo Real, Jornalismo Virtual". Ainda em 1986 se procurava valorizar a imprensa escrita, com o lançamento da campanha a favor da divulgação do papel e do valor da imprensa escrita.

\section{As primeiras exposições de imprensa}

As Exposições de Jornalismo e Arte Tipográfica, realizadas meses antes nas salas do Ateneu Comercial de Lisboa, integraram-se nas festas nacionais que solenizaram o $4^{\circ}$ centenário do descobrimento do caminho marítimo para a Índia. Jornalistas como Silva Pereira, Alberto Bessa, Heliodoro Salgado, Silva Leal, entre outros membros da comissão promotora e membros da Associação da Imprensa Portuguesa (criada em 1897), impulsionaram a primeira mostra de jornais, que o país pôde visitar, em Lisboa, entre 14 e 30 de Maio de 1898. A Alberto Bessa, autor da 
proposta da exposição, e a Silva Leal se ficou a dever o êxito da iniciativa, como o reconheceram os seus contemporâneos.

A abertura solene ocorreu em 14 de Maio de 1898, numa das salas do Ateneu, completamente cheia de senhoras e das mais conhecidas individualidades do jornalismo português. Aberta a sessão, seguiram-se os discursos de Magalhães Lima, Rodrigo Veloso, Heliodoro Salgado e Gomes da Silva (Bessa, 1898, pp.10-19). A exposição da imprensa, "pela sua originalidade e beleza, foi um dos números mais notáveis desses festejos comemorativos" (Occidente, vol. XXI, n. ${ }^{\circ} 700$, pp. 130-131). Com 197 expositores, houve trabalhos premiados. Entre o material mostrado, surpreendeu a magnífica colecção do fotógrafo Gião intitulada a "Imprensa portuguesa". Anexas à sala estavam a exposição tipográfica e as fotografias.

A citada revista Occidente divulgou-as com grande amplitude, assim como aos seus promotores, traçando deles pequenos perfis biográficos, acompanhados dos seus retratos como um agradecimento da classe jornalística: Silva Leal era filho do escritor e conselheiro José Maria da Silva Leal e possuidor de uma copiosa colecção de jornais. Alberto Bessa era, então, um dos mais esclarecidos redactores de $O$ Século (a ele se ficou a dever em, grande parte, o sucesso da exposição da imprensa); Heliodoro Salgado, jornalista de raça, polemista de pulso e orador insinuante (era também o director político de $A$ Vanguarda); Andrade Neves, um dos mais denodados evangelizadores das regalias e interesses populares; Ludgero Viana, que foi presidente da Associação da Imprensa e membro da comissão promotora e esteve mais de vinte anos no Diário Ilustrado e foi redactor do Correio da Europa; A. X. Silva Pereira, que se salientou pelos seus artigos de investigação histórica dispersos por vários jornais (os seus muitos trabalhos de investigação referentes ao jornalismo português eram a sua principal glória).

Dirigido por Alberto Bessa, publicou-se, ainda em 1898, um número único sobre o primeiro certame jornalístico que se realizou em Portugal por ocasião do centenário indiano, com oito páginas e nove gravuras intitulado $A$ Exposição da Imprensa.

\section{Das primeiras associações de jornalistas ao sindicato}

Só no século XIX o jornalismo se tornou uma profissão e os jornalistas adquiriram consciência do poder da sua acção colectiva. A partir de 1880, 
mais de uma dezena de associações se fundaram. As associações de homens de letras, escritores e publicistas em Portugal também têm as suas raízes no século XIX. Naturalmente, os seus objectivos não foram sempre os mesmos e, de um modo geral, podemos afirmar que foram evoluindo, defendendo a promoção da instrução, os melhoramentos da imprensa, a protecção social e a escola de jornalismo.

Antes do aparecimento da primeira Associação de Jornalistas e Escritores Portugueses, criada em 1880, recorde-se a existência de uma Sociedade dos Amigos das Letras, em 1823 e 1836, impulsionada pelos irmãos Castilhos; da Academia Lisbonense das Ciências e das Letras, presidida por Silvestre Pinheiro Ferreira, em 1843; do Grémio Literário, criado em Lisboa, em 1846, por Garrett, Rodrigo da Fonseca, Fontes Pereira de Melo e Oliveira Marreca; da Liga Promotora dos Melhoramentos da Imprensa, criada em 1846 e onde se salientou José Estevão; da Sociedade dos Amigos das Letras e Artes de S. Miguel, que apareceu em 1848; e da Sociedade de Homens de Letras, proposta, num jantar de escritores, por António Augusto Teixeira de Vasconcelos, em 1870, à imitação da que existia em França, mas que não se concretizou.

Várias associações especificamente formadas por jornalistas constituíram-se em Portugal, em contextos políticos, sociais e culturais diversos, desde 1880, procurando a valorização social dos escritores e dos jornalistas: a Associação de Jornalistas e Escritores Portugueses, em Lisboa (1880); a assinalada Associação de Jornalistas e Homens de Letras, no Porto (1882); a Associação dos Jornalistas, em Lisboa (1896); a Associação da Imprensa Portuguesa, em Lisboa (1897); a Associação de Classe dos Trabalhadores da Imprensa de Lisboa (1904); a Associação dos Jornalistas e Escritores Portugueses ( $\left(2^{\mathrm{a}}\right)$, em 1907; a Casa dos Jornalistas (1921); o Sindicato dos Profissionais da Imprensa de Lisboa (1924); o Sindicato Nacional dos Jornalistas Portugueses (1940); a Associação de Jornalistas de Coimbra (1930).

Recentemente, a valorização da profissão e a identidade jornalística foram definidas pela Constituição de 1976, pelo Conselho de Imprensa, em 1978, e pelo Estatuto do Jornalista, em 1979. Hoje, ainda não existe uma Ordem dos Jornalistas, mas não se deve esquecer que ela já foi pensada nos anos quarenta do século XX.

A Associação de Jornalistas e Escritores Portugueses foi criada em Lisboa, em 1880, no âmbito do programa das comemorações camonianas, com o fim de estabelecer uma biblioteca de jornalismo e de lançar o 
embrião de uma Escola de Jornalismo. Mendes Leal sintetizou o seu aparecimento, bem como a evolução do jornalismo em Portugal, da seguinte forma: "O ascendente influxo da imprensa - instrumento, deu origem à imprensa - instituição; e do desenvolvimento da imprensa instituição, com as suas contingências e riscos, espontaneamente brotou a imprensa-associação". (cit. em Cunha, 1941, p. 12). Como se salientou, no cortejo cívico camoniano de 1880, um dos carros triunfais representou a imprensa e, simbolicamente, todos os representantes dos jornais e associações a ela ligados aí se integraram através dos seus representantes; o mesmo aconteceu nos cortejos pombalino, em 1882, e garretiano, em 1903.

O publicista portuense Joaquim de Vasconcelos apresentou na Sociedade de Geografia de Lisboa, em 1879, uma proposta para celebrar o tricentenário de Camões, onde também sugeriu a ideia de se nomear uma comissão para estudar e formular o programa da festa por parte do jornalismo de Lisboa. O jornalista e director do Diário de Notícias, Eduardo Coelho, defendeu que, entre outras manifestações da imprensa, se incluísse a fundação, no dia 10 de Junho de 1880, da Associação dos Jornalistas e Escritores Portugueses. E Ramalho Ortigão, o redactor do programa definitivo das comemorações, incluiu nele a inauguração da Associação, cuja finalidade seria criar uma biblioteca do jornalismo português, um cofre de ajuda editorial, um júri para resolver conflitos de imprensa, e de organizar cursos livres de ciências naturais e sociais. A Associação foi precursora na ideia de formação de uma escola de jornalistas, proposta que virá a estar igualmente presente no Congresso Internacional da Imprensa, de 1898.

Os Estatutos desta Associação foram redigidos a partir das bases apresentadas por Eduardo Coelho, sendo aprovados por um Alvará de 14 de Outubro de 1880. Mas antes, a 10 de Junho, na sala da primeira sede da Sociedade de Geografia, foi lavrada a acta da sessão solene que instituiu a Associação e que foi presidida por António Rodrigues Sampaio, então o decano dos jornalistas portugueses.

O escol da literatura, da ciência e do jornalismo daquela época fez parte desta pioneira Associação. Entre os duzentos e quarenta e dois sócios fundadores, estavam jornalistas como António Rodrigues Sampaio, António Enes, Emídio Navarro, Sousa Viterbo, Júlio César Machado, Mariano de Carvalho, Brito Aranha, Urbano de Castro; publicistas como Adolfo Coelho, António de Serpa, Andrade Corvo, 
Fernandes Costa, Vilhena Barbosa, Latino Coelho, Joaquim de Vasconcelos, José Júlio Rodrigues, José Silvestre Ribeiro, Júlio de Vilhena, Luciano Cordeiro, Visconde de Castilho; poetas como Tomás Ribeiro, Mendes Leal, Gonçalves Crespo, Rodrigues Cordeiro, Gomes Leal, Fernando Caldeira, Eduardo Vidal, Bulhão Pato; professores como o Conde de Ficalho, Ferreira Lapa, Fonseca Benevides, Oliveira Feijão, Silvestre Bernardo Lima, Sousa Martins, Tomás de Carvalho, e a escritora Guiomar Torresão.

Em 1881, a Associação realizou uma exposição de obras camonianas, um congresso das associações, e deu sequência ao programa das lições de história universal proferidas por Consiglieri Pedroso, realizando-se, em 1882, um curso público.

Em Junho de 1884, editou o primeiro Boletim e, no ano seguinte, procedeu a uma reforma dos Estatutos com o sentido de reanimar as tarefas que pretendia ver realizadas. No entanto, esta Associação não sobreviveu para além de 1892, não concretizando os seus objectivos. Escrevia-se no jornal Repórter, de 28 de Fevereiro de 1892: "a Associação não desenvolveu influência alguma. A pouco trecho, e dentro da mesma sala, os regeneradores olhavam de soslaio para os republicanos; os progressistas desconfiavam dos regeneradores; e a unidade de acção e de trabalho foi desaparecendo. As salas tornaram-se desertas [...] Provou-se sobejamente que numa capital onde há associações de todo o género, desde os cozinheiros e vendedores de jornais, até aos capitalistas e salvadores da pátria, não era viável uma associação de jornalistas".

A segunda associação, a Associação dos Jornalistas e Homens de Letras do Porto, foi fundada em 13 de Outubro de 1882 para homenagear e honrar a memória de António Rodrigues Sampaio, entretanto falecido. Um dos membros fundadores foi o jornalista João Chagas. Esta foi a associação de imprensa mais duradoura em Portugal, alcançando grande prestígio e defendendo os interesses dos seus associados. Coube-lhe também o mérito de ter criado a Casa dos Jornalistas, em 1921.

A Associação dos Jornalistas nasceu em 1896, em Lisboa, sob o impulso dos jornalistas Trindade Coelho, Alfredo da Cunha e Lourenço Cayolla, e dos escritores Pedro Venceslau de Brito Aranha e Sebastião de Magalhães Lima. Era seu intento fazer ressuscitar a antiga Associação. Os seus Estatutos foram redigidos por Trindade Coelho e aprovados por Alvará de 24 de Setembro de 1896. Dela podiam fazer parte "os escritores com tirocínio na imprensa periódica, quer façam do jornalismo ou 
não a sua ocupação habitual e exclusiva, com reconhecida capacidade moral" (Cunha, 1941, p. 20). A Associação defendeu os jornais e os jornalistas num dos momentos mais agitados, política e socialmente, que o país viveu, e em que se verificaram frequentes ataques à liberdade de imprensa. A esta Associação, que teve como sede provisória as instalações do Diário de Notícias, se ficou a dever a organização do primeiro congresso internacional de imprensa realizado em Portugal (1898).

Entre outras actividades desenvolvidas por esta Associação, destacaram-se: a celebração do centenário do nascimento de Vítor Hugo, a homenagem a Rafael Bordalo Pinheiro; o inquérito sobre os meios práticos de extinguir o analfabetismo, e as conferências literárias realizadas pelo professor Consiglieri Pedroso.

Apesar da remodelação dos Estatutos, em Fevereiro de 1907, e da mudança do nome para Associação dos Jornalistas e Escritores Portugueses, ela entrou também em decadência.

A Associação da Imprensa Portuguesa foi fundada em Lisboa, em Setembro de 1897, por iniciativa dos jornalistas Alberto Bessa, José de Lemos, Vieira Correia e Ludgero Viana, e os seus Estatutos foram aprovados pelo Alvará de 14 de Julho de 1898. Coexistiu com a Associação dos Jornalistas. Caracterizou-se por ter feito um recrutamento mais democrático de sócios e também por uma quotização menos onerosa. Pertenceram-lhe mais de uma centena de sócios efectivos, beneméritos, honorários e correspondentes, oriundos de todo o país. Como curiosidade, refira-se que o redactor de $O$ Conimbricense, Joaquim Martins de Carvalho, e a escritora Guiomar Torresão foram seus associados. Foi esta Associação que dinamizou a Exposição de Imprensa, realizada no Ateneu Comercial de Lisboa, acima referida, "primeiro certame do seu género entre nós, e um dos grandes sucessos práticos das festas comemorativas do quarto centenário do descobrimento do caminho marítimo para a Índia" (Cunha, 1941, p. 26).

A Associação da Imprensa Portuguesa participou no Congresso Internacional de Lisboa, de 1898, através dos sócios Francisco Eusébio Leão, J. V. de Andrade Neves e Francisco Guilherme de Sousa. Este último redigiu uma mensagem de saudação escrita em francês. Como visava apresentar a opinião da Associação sobre a imprensa, foi enviada a todos os participantes, mas não chegou a ser discutida.

$\mathrm{O}$ ano de 1898 foi também um ano de inúmeras querelas por delito de imprensa. Por esse motivo, as leis de imprensa foram objecto de 
tratamento por parte da Associação: em 18 de Fevereiro de 1899 enviou ao Parlamento uma representação em defesa dos interesses da classe.

Em 1903, a Associação colaborou no centenário de Garrett, publicando um número único, Garrett, um êxito editorial esgotado em três dias.

Como rivais que foram, as duas Associações (a dos jornalistas e a da imprensa), enquanto existiram, não se aliaram e só tardiamente se uniram na Associação de Jornalistas e Escritores Portugueses.

A Associação dos Trabalhadores da Imprensa de Lisboa teve os seus Estatutos aprovados pelo Alvará de 24 de Abril de 1905; foi a quarta Associação deste tipo que se fundou em Lisboa, reunindo no seu seio todos os que exercessem actividade profissional na imprensa periódica de Lisboa. Tinha como finalidade o estudo e a defesa dos interesses económicos comuns aos associados, a organização de uma biblioteca, e a fundação de aulas para os sócios e os seus filhos. Nos Relatórios de 1911 e de 1918 provava-se que era a única Associação que cumpria a sua missão. Após a reforma dos Estatutos, em 1924, passou a intitular-se Sindicato dos Profissionais da Imprensa de Lisboa e editou o primeiro Boletim em 1926, tendo por objectivos os mesmos das anteriores Associações e, particularmente, lutar pelo estabelecimento de uma escola de jornalismo.

Em 1940, criou-se o Sindicato Nacional dos Jornalistas, cujos Estatutos foram aprovados pelo Alvará de 16 de Outubro. O Boletim do Sindicato Nacional dos Jornalistas, apenas editado entre 1941 e1945, teve como Director Luís Teixeira, e os seus cinco números mensais são uma importante fonte para a história do jornalismo em Portugal. Entre outros artigos relevantes aí apresentados, salientam-se o primeiro Curso de Formação Jornalística e os artigos sobre o tricentenário da Gazeta, reunidos num número especial em 1941.

O aperfeiçoamento intelectual e moral da classe jornalística foi uma tarefa a que as Associações e o Sindicato procuraram dar resposta com o fim de afirmar a profissão.

\section{Os primórdios do ensino do jornalismo}

Em 1880, através da Associação de Jornalistas e Escritores Portugueses, e, em 1898, no âmbito do Congresso Internacional de Lisboa, começou a esboçar-se a ideia da criação do ensino do jornalismo em Portugal, visto como um dos meios de afirmação dos jornalistas. 
Na Europa, sabe-se que a primeira escola de jornalismo foi fundada em Paris, em Novembro de 1899, pelo impulso dos jornalistas Albert Bataille e Périvier; mas a instituição do ensino superior do jornalismo teve antecedentes, desde 1869, nos Estados Unidos da América. A ideia de um ensino especializado no domínio do jornalismo foi aí dinamizada por Joseph Pulitzer, e o primeiro curso superior de jornalismo, depois de tentativas anteriores, começou a funcionar, em 1908, na Universidade de Columbia, Missouri, organizado pelo jornalista Walter Williams.

Em Portugal, em 1916, um jornal da capital abriu um inquérito sobre a importância de uma escola de jornalistas. Um dos entrevistados, Alfredo da Cunha, respondeu favoravelmente à ideia: "Claro que tais escolas não formam no rigor do termo, jornalistas. $O$ verdadeiro jornalista, como o verdadeiro actor, como o verdadeiro artista, como o verdadeiro homem de negócios, nasce já com determinadas faculdades, que as escolas não fazem senão adestrar. E, em jornalismo, como em outra carreira, a vocação é ainda o principal" (Cunha, 1941).

Data de 1941 a proposta do Sindicato de Jornalistas para a criação de um curso de formação jornalística, de dois anos, com o fim de promover a valorização profissional da classe. No entanto, e ao contrário de Espanha, onde, no mesmo ano, se criou a Escola Oficial de Periodismo, a iniciativa do Sindicato acabaria por não se concretizar, e só nos finais dos anos setenta o ensino superior do jornalismo se tornou realidade, constituindo-se, na década seguinte, o Centro de Formação de Jornalistas.

Já em outro contexto político não deixou o Sindicato de reforçar a ideia: em 1971, a direcção, presidida por Manuel da Silva Costa, apresentou um projecto de ensino do jornalismo (Mesquita, 1994). O então Ministro da Educação Nacional, Veiga Simão, defendeu outra ideia, a instalação de um Instituto Superior de Ciências da Informação. Daí até hoje deu-se o "milagre da multiplicação de cursos" (Mesquita, 1994). Como não deixar de ver, na extraordinária proliferação de cursos de ensino superior do jornalismo, desde 1979, um sinal da valorização social das profissões dos media e, provavelmente, também um sinal da crise das saídas tradicionais na área das ciências humanas?

As bases de uma identidade jornalística em Portugal estão criadas no novo contexto político democrático depois de 1974, através de vários institutos: a Lei de Imprensa, de 26 de Fevereiro de 1975, e a defesa $\left(\mathrm{Art}^{\circ} 62^{\circ}\right)$ do exercício do ensino superior do jornalismo; o Conselho de Imprensa - instituído pela lei de 20 de Junho de 1978, que tinha como 
atribuição (Art. ${ }^{\circ} 2^{\circ}$ ) "zelar pela independência da imprensa face ao Poder Político e económico; por uma orientação que respeite o pluralismo ideológico"; o Estatuto do Jornalista, criado pela lei de 20 de Setembro de 1983.

Em conclusão: é legítimo afirmar que o jornalismo foi, no início, uma actividade pouco prestigiada, mas que, a pouco e pouco, se foi afirmando profissionalmente. Por isso, hoje, a questão do seu poder relativo deve ser colocada mais do que no passado. O mito do "quarto poder", ou do verdadeiro poder, nasceu quando a informação se tornou uma dimensão do próprio poder.

Nos séculos XIX e XX, ao mesmo tempo que a profissão se afirmou perante políticos, escritores, publicistas e outros intelectuais, cada vez mais se começou a desenvolver uma imagem contraditória sobre o poder do jornalismo, situação muito ampliada nos nossos dias, onde se assiste à clara emergência do jornalismo como uma actividade de contra-poder, ou melhor, de um poder vigilante e crítico.

Referências bibliográficas citadas:

Agee, W. e Traquina, Nelson (1988) - O quarto poder frustrado. Os meios de comunicação social no Portugal pós revolucionário, Lisboa, Veja.

Balzac, Honoré de (1998, $1^{\text {a }}$ edição em 1843) - Les journalistes, Paris, Arlea.

Bessa, Alberto, (1898) - A Associação de Imprensa Portuguesa no segundo ano da existência, Relatório, Lisboa, Typ. do Expresso.

Boletim da Associação de Jornalistas e Escritores Portugueses, $1^{\text {a }}$ Série, $\mathrm{n}^{\circ}$ 1, 10 de Junho 1884, Lisboa, Typ. Armando Rosa.

Boletim da Associação dos Jornalistas e Homens de Letras do Porto, $\mathrm{n}^{\circ} 1$ e 2, Porto, Dez. 1932 e Jan-Mar. 1933.

Boletim do Sindicato Nacional dos Jornalistas, n. ${ }^{\circ} 1$ a 5, 1941-1945.

Catroga, Fernando (1991) - O Republicanismo em Portugal: da formação ao cinco de Outubro de 1910, Fac. de Letras, Coimbra, 2 vols.

Catroga, Fernando, (1996), "Ritualizações da história", História da História em Portugal. Sécs. XIX e XX, Lisboa, Círculo de Leitores, pp. 547-671. 
Cunha, Alfredo (1941) - Jornalismo Nacional. Das malogradas Associações de imprensa à alvitrada Ordem dos jornalistas portugueses, Conferência, sep. do Boletim do Sindicato Nacional dos Jornalistas, $\mathrm{n}^{\circ} 2$.

Cunha, Alfredo da (1914) - O Diário de Notícias. A sua fundação e os seus fundadores, Lisboa, edição comemorativa.

Delporte, Christian (1999) - Les journalistes en France, 1880-1950, Paris, Seuil.

Ferenczi, Thomas (1996) - L'invention du journalisme en France, Paris, Payot.

Guénaire, Michel (2002) - Déclin et renaissance du pouvoir, Paris, Gallimard.

Jornalismo e Literatura. Actas do II Encontro Luso-Afro-Brasileiro (1988) - Lisboa, Veja. Mesquita, Mário (1994) - "A educação para o jornalismo", Intercom, S. Paulo, pp. 75-97.

Mesquita, Mário (2003) - O quarto equívoco. O poder dos media na sociedade contemporânea, Coimbra, MinervaCoimbra.

Nemésio, Vitorino (1943) - "O problema do jornalismo", Boletim do Sindicato, $\mathrm{n}^{\circ}$ 5, pp. 55-59.

Ribeiro, Maria Manuela Tavares (1993) - O centenário henriquino: imagens e ideologia, sep. da Revista de História das Ideias, n 15, pp. 331-378.

Ribeiro, Maria Manuela Tavares (1984) - Subsidios para a história da liberdade de imprensa: meados do século XIX, sep. de Boletim do Arquivo da Universidade, vol. 6, pp. 461-593.

Rieffel, Rémy (1984) - L'elite des journalistes. Les herauts de l'information, Paris, PUF.

Santos, Maria de Lourdes Lima dos (1983) - "Os fabricantes dos gozos da inteligência - alguns aspectos da organização do mercado de trabalho intelectual no Portugal Oitocentista", Análise Social, vol. XIX (75), pp. 7-28.

Santos, Maria de Lourdes Lima dos (1988) - Intelectuais Portugueses na primeira metade de Oitocentos, Lisboa, Presença.

Teixeira, Luiz, (1945) - "Que é ser jornalista?", Boletim do Sindicato, nº 5, p. 135.

Traquina, Nelson (2002) - O que é jornalismo, Lisboa, Quimera Ed.

Veríssimo, Helena Ângelo (2003) - Os jornalistas nos anos 30/40. Elite do Estado Novo, Coimbra, MinervaCoimbra. 